\title{
ANALISIS PENGARUH PEREKONOMIAN MAKRO DAN MIKRO YANG BERPENGARUH PADA RISIKO SISTEMATIS SAHAM
}

\author{
Ming Chen \\ STIE Musi Palembang \\ Mingchen133@yahoo.co.id
}

\begin{abstract}
Abstrak: Penelitian ini dilaksanakan dengan tujuan untuk mengetahui pengaruh perekonomian makro (kurs, inflasi, suku bunga SBI dan jumlah uang beredar) dan mikro (Asset Growth dan Debt to Equity) terhadap risiko sistematis pada perusahaan LQ-45 yang terdaftar di Bursa Efek Indonesia (BEI). Data tahunan untuk variabel makroekonomi selama tahun 2006-2012 dan data bulanan yang akan diolah menjadi data tahunan untuk variabel mikro dan risiko sistematis selama periode januari 2006 sampai Desember 2012. Data dianalisis dengan menggunakan analisis regresi berganda. Hasil penelitian ini membuktikan bahwa tingkat inflasi, kurs, jumlah uang beredar, tingkat suku bunga SBI, DER dan Aset Growth berpengerahu secara simultan terhadap risiko sistematis saham. Tingkat inflasi, kurs, dan jumlah uang beredar tidak berpengaruh secara parsial terhadap risiko sistematis saham sedangkan DER dan asset growth berpengaruh secara parsial terhadap risiko sistematis saham.
\end{abstract}

Kata Kunci : Makro, Mikro, Risiko Sistematis Saham

Abstract: This research was conducted to determine the influence of mcro economy (exchange rate, inglation, interest rate of SBI and the amount of supplied money) and micro economy (asset growth and debt to equity) to the systematic risk in LQ-45 companies listed in Indonesia Stock Exchange. Annual data for macro economic variables during the period of 2006-2012 and monthly data were processed into annual data for micro variables and systematic risk during the period of January 2006 to December 2012. The data were analyzed by multiple regression analysis. The result showed that inflation and exchange rate, money supply, interest rate of SBI, DER and Asset growth simultaneously influence the systematic risk of stocks. Thus, the inflation $n$ exchange rate and money suplly do not partially affect the systematic risk of stock. Meanwhile, DER and Asset growth partially influence the systematic risk of stocks.

Key words : Macro, Micro, The Systematic Risk of Stocks.

\section{PENDAHULUAN}

\section{Latar Belakang}

Pasar modal (capital market) pada prinsipnya merupakan pasar untuk sekuritas jangka panjang baik berbentuk hutang maupun ekuitas (modal sendiri) serta berbagai produk turunannya. (Tandelilin, 2010). Saham merupakan salah satu sekuritas di antara sekuritas-sekuritas lainnya yang mempunyai tingkat risiko yang tinggi. Risiko tinggi tercermin dari ketidakpastian return yang akan diterima oleh investor di masa datang. Terdapat dua aspek yang melekat dalam suatu investasi yaitu tingkat pengembalian (return) yang diharapkan dan risiko tidak tercapainya return yang 


\section{JURNAL NOMINAL / VOLUME III NOMOR 2 / TAHUN 2014}

diharapkan. Risiko yang tinggi pada saham berhubungan dengan kondisi ekonomi makro, seperti resesi ekonomi, gejolak politik, dan lain sebagainya serta industri dan karakteristik perusahaan. (Hamzah, 2005). Pasar modal laksana pendulum petunjuk arah, dimana naik dan turunnya umumnya mengekspresikan realitas gambaran dari kondisi ekonomi, politik sekaligus optimisme menatap masa depan (Susanto, 2002). Pasar modal di Indonesia pernah mengalami tantangan yang cukup berat sejak akhir tahun 1997, bersamaan dengan terguncangnya sendi-sendi perekonomian Indonesia akibat hantaman krisis ekonomi yang melanda hampir seluruh kawasan Asia. Krisis ini ditandai dengan menurunnya nilai kurs, meningkatnya suku bunga deposito, dan SBI yang berada diatas 60 persen per tahun, serta jumlah uang beredar yang meningkat cukup signifikan diikuti peningkatan inflasi yang cukup tajam.

Selama periode krisis ini kondisi pasar modal pun ikut terpuruk, Indeks Harga Saham Gabungan mengalami koreksi yang cukup besar dari kisaran harga 726 pada pertengahan tahun 1997 menjadi kurang lebih 260. Penurunan laba yang dialami sebagian besar emiten, penurunan aktivitas, nilai transaksi, dan kesulitan finansial yang dialami merupakan konsekuensi yang diperoleh dari krisis ekonomi yang terjadi. Faktor yang secara teoritis dipertimbangkan dalam investasi saham adalah risiko. Risiko merupakan terjadinya penyimpangan atas keuntungan yang diharapkan. Misalkan terdapat suatu perusahaan yang tidak efisien dalam operasi produksinya. Hal ini menyebabkan perusahaan tersebut menggunakan hutang yang tinggi dalam produksinya yang mengakibatkan biaya tetap perusahaan menjadi tinggi dan apabila suatu saat perusahaan tersebut gagal, maka kepentingan investor dalam mendapatkan laba diperusahaan tersebut menjadi terancam. Oleh karena itu, investor juga perlu melihat seberapa besar risiko yang harus ditanggungnya dalam berinvestasi. Beberapa peneliti sebelumnya telah melakukan penelitian untuk mengetahui pengaruh variabel ekonomi makro dan mikro terhadap risiko sistematik seperti Makaryanawati dan Ulum (2008), Hamzah (2005), Haryanto dan Riyatno (2007), Ocran (2010), dan Tandelilin (1997). Penelitian Makaryanawati dan Ulum (2008) menemukan bahwa tingkat suku bunga berpengaruh signifikan terhadap risiko sistematik saham namun tingkat likuiditas yang ditunjukkan oleh rasio lancar (current ratio) tidak berpengaruh signifikan terhadap risiko investasi saham. Dalam penelitian yang dilakukan oleh Hamzah (2005) menemukan bahwa secara simultan variabel makro, karakteristik perusahaan dan industri berpengaruh terhadap beta saham syariah. Dalam penelitian Tandelilin (1997) menemukan bahwa variabel fundamental 
secara simultan berpengaruh terhadap beta saham sedangkan variabel makro secara simultan tidak berpengaruh terhadap beta saham. Dalam penelitian yang dilakukan oleh Haryanto dan Riyatno (2007) selain menemukan bahwa tingkat suku bunga berpengaruh signifikan terhadap risiko sistematik saham, ditemukan juga pengaruh yang signifikan antara nilai kurs dan risiko sistematik. Penelitian yang dilakukan Ocran (2010) menemukan bahwa Perekonomian Negara Ghana tidak berpengaruh pada resiko sistematik saham karena saham yang terdaftar di Ghana Bursa Efek adalah saham defensive dengan tingkat beta kurang dari satu. Adanya pertentangan dalam kajiankajian sebelumnya dan berdasarkan fenomena yang ada, dirasakan perlu untuk melakukan penelitian lain yang mengkaji mengenai pengaruh kurs, inflasi, tingkat suku bunga SBI, jumlah uang beredar, debt to equity dan asset growth terhadap risiko sistematis saham pada perusahaan LQ-45. Berdasarkan uraian diatas maka judul dari penelitian ini adalah Analisis Pengaruh Perekonomian Makro dan Mikro Terhadap Risiko Sistematis Saham :Studi Empiris Pada Perusahaan LQ-45 di Bursa Efek Indonesia.

\section{Rumusan Masalah Penelitian}

Terkait dengan beberapa hal di atas maka dapa dirumuskan pertanyaan penelitian sebagai berikut :
1. Apakah terdapat pengaruh antara kurs, inflasi, suku bunga SBI, jumlah uang beredar, DER dan asset Growth secara simultan (bersama-sama) terhadap risiko sistematis saham pada perusahaan LQ$45 ?$

2. Apakah terdapat pengaruh antara kurs, inflasi, suku bunga SBI, jumlah uang beredar, DER dan asset growth secara parsial (sendiri-sendiri) terhadap risiko sistematis saham pada perusahaan LQ$45 ?$

\section{Tujuan Penelitian}

Berdasarkan rumusan masalah yang telah dinyatakan diatas, maka tujuan dari peneltian ini adalah sebagai berikut:

1. Ingin menganalisis pengaruh kurs, inflasi, suku bunga SBI, jumlah uang beredar, debt to equity dan asset growth secara simultan (bersamasama) terhadap risiko sistematis saham pada perusahaan LQ-45.

2. Ingin menganalisis pengaruh kurs, inflasi, suku bunga SBI, jumlah uang beredar, debt to equity dan asset growth secara parsial (sendiri-sendiri) terhadap risiko sistematis saham pada perusahaan LQ-45.

\section{Manfaat Penelitian}

Hasil penelitian ini diharapkan dapat memberikan manfaat bagi berbagai pihak, antara lain : 


\section{JURNAL NOMINAL / VOLUME III NOMOR 2 / TAHUN 2014}

1. Secara Teoritis

Sebagai input dan bahan perbandingan mengenai konsep dan teori ilmu pengetahuan akuntansi keuangan, khususnya mengenai faktor-faktor yang mempengaruhi risiko sistematis saham.

2. Secara Praktis

1) Investor

Sebagai bahan pertimbangan bagi investor agar dapat membuat keputusan investasi mengenai pemilihan jenis saham perusahaan dan waktu berinvestasi dengan tepat di pasar modal Indonesia.

2) Regulator/Pemerintah

Sebagai bahan pertimbangan bagi pemerintah dalam menentukan kebijakan yang mempengaruhi variabel-variabel makroekonomi terkait pasar modal.

3) Bursa Efek Indonesia

Sebagai bahan pertimbangan bagi para pialang yang bekerja di Bursa efek Indonesia dalam melakukan analisis saham.

4) Bagi Peneliti

Diharapkan hasil penelitian ini dapat dibermanfaat bagi semua pihak dan dapat memberikan bukti empiris mengenai analisis pengaruh faktorfaktor yang berpengaruh terhadap risiko sistematis.

\section{Teori Portofolio}

Konsep dari resiko portofolio pertama kali diperkenalkan oleh Markowitz (1950). Teori portofolio merupakan teori yang berhubungan mengenai pengembalian portofolio yang diharapkan dan tingkat risiko portofolio yang dapat diterima, serta menunjukkan cara pembentukan portofolio yang optimal. Teori portofolio ini saling berkaitan dengan teori pasar modal yang berdasar pada pengaruh keputusan investor terhadap harga sekuritas serta menunjukkan hubungan yang seharusnya terjadi antara pengembalian dan risiko sekuritas jika investor membentuk portofolio yang sesuai dengan teori portofolio.

Dalam membentuk suatu portofolio terdapat permasalahan yakni terdapat banyak sekali kemungkinan portofolio yang dibentuk dari kombinasi aktiva beresiko yang tersedia di pasar. Portofolio yang dipilih oleh investor adalah portofolio optimal. Portofolio optimal ditentukan dengan menggunakan model Markowitx atau model indeks tunggal. Untuk menentukan portofolio yang optimal dengan model-model ini yang pertama kali dibutuhkan adalah menentukan portofolio optimal.

\section{Risiko Sistematis Saham}

Dalam melakukan investasi, investor selalu memperhatikan return yang diharapkan dengan risiko yang harus ditanggung atas investasinya. Hubungan risiko dan return 


\section{JURNAL NOMINAL / VOLUME III NOMOR 2 / TAHUN 2014}

yang diharapkan dari suatu investasi merupakan hubungan searah dan linier. Semakin besar risiko yang ditanggung, semakin besar pula tingkat return yang diharapkan. Hubungan inilah yang menyebabkan tidak semua investor berinvestasi pada aset yang menawarkan tingkat return yang tinggi. Di samping memperhatikan return yang tinggi, investor juga harus mempertimbangkan tingkat risiko yang harus ditanggung. Risiko ini timbul karena adanya ketidakpastian.

Investor yang tidak terlalu menyukai risiko akan menempatkan sebagian investasinya pada aset risiko rendah seperti SBI (Sertifikat Bank Indonesia). Investasi pada SBI dapat dikatakan tidak berisiko karena Bank Indonesia dapat dipastikan akan melunasi kewajibannya pada saat jatuh tempo. Karena resikonya yang sangat rendah, maka investasi pada SBI hanya dapat memberikan return yang relatif kecil. Investasi pada obligasi mempunyai risiko yang lebih tinggi, tetapi masih lebih rendah dibandingkan risiko saham. Investasi pada obligasi mempunyai risiko tidak dapat dilunasi kewajibannya pembayaran bunga dan/atau pelunasan obligasi apabila perusahaan yang mengeluarkan obligasi mengalami kesulitan keuangan. Sedangkan investasi pada saham mempunyai risiko yang lebih tinggi lagi. Investasi pada saham mempunyai risiko yang tinggi dikarenakan return yang diharapkan pada suatu periode tertentu tidak dapat direaliasikan.

\section{Inflasi dan Risiko Sistematis Saham}

Inflasi merupakan kenaikan harga-harga secara umum dan terus menerus untuk periode waktu tertentu. Inflasi adalah variabel makroekonomi yang dapat sekaligus menguntungkan dan merugikan suatu perusahaan. Pada dasarnya inflasi yang tinggi tidak disukai oleh pelaku pasar modal karena akan meningkatkan biaya produksi yang akan berdampak buruk pada harga produk yang dijual dan pendapatan. Namun disisi lain inflasi juga akan meningkatkan harga jual produk perusahaan tersebut. Jika margin pendapatan lebih tinggi daripada margin biaya maka perusahaan akan memperoleh keuntungan dari inflasi tetapi hal sebaliknya yang lebih sering terjadi.

Hooker (2004) menemukan bahwa tingkat inflasi mempengaruhi secara signifikan terhadap harga saham. Makin tingginya inflasi makin menurunkan profitabilitas perusahaan. Turunnya profitabilitas perusahaan merupakan informasi yang buruk bagi para investor di bursa saham sehingga dapat mengakibatkan turunnya harga saham perusahaan tersebut, sehingga akan menurunnya risiko yang akan ditanggung oleh investor. 


\section{JURNAL NOMINAL / VOLUME III NOMOR 2 / TAHUN 2014}

\section{Tingkat Suku Bunga SBI dan Risiko} Sistematis

Tingkat bunga merupakan alat penyimpan kekayaan dan sebagai variabel penghubung antara pasar uang dan pasar barang atau harga dari penggunaan uang untuk jangka waktu tertentu. Kaum klasik berpendapat, bunga merupakan harga dari penggunaan loanable funds atau harga yang terjadi di pasar dana investasi dalam suatu periode tertentu. Kenaikan suku bunga akan menyebabkan investor kurang berminat melakukan investasi karena bunga pinjaman yang harus dibayarkan menjadi lebih tinggi.

Pada kondisi ini investor lebih tertarik untuk menyimpan dana di bank dan memperoleh pendapatan dari bunga tabungan sehingga pasar saham menjadi tidak menarik. Peningkatan suku bunga akan mendorong peningkatan biaya pada perusahaan yang memiliki jumlah kewajiban yang besar. Peningkatan biaya ini akan menurunkan laba perusahaan dan kemampuan perusahaan untuk membagikan dividen. Dengan menurunnya laba dan kemampuan perusahaan membagikan dividen akan mengurangi minat investor untuk berinvestasi pada perusahaan tersebut sehingga banyak investor yang melepaskan investasinya. Semakin banyak investor yang melepaskan atau menjual saham maka harga saham perusahaan tersebut akan turun dan akhirnya berimbas pada penurunan return serta risiko sistematik. (Kewal, 2011)

\section{Jumlah Uang Beredar dan Risiko Sistematis}

Jumlah uang beredar adalah nilai keseluruhan uang yang berada di tangan masyarakat. Semakin tinggi jumlah uang beredar dalam masyarakat maka masyarakat memiliki kelebihan dana untuk melakukan investasi. Jumlah uang beredar dengan pertumbuhan yang wajar memberikan pengaruh positif terhadap ekonomi dan pasar modal secara jangka pendek. Namun pertumbuhan yang drastis akan memicu inflasi yang tentunya memberikan pengaruh negatif terhadap pasar modal (Nugroho, 2008).

Jumlah uang beredar memiliki pengaruh terhadap risiko sistematik dimana jika jumlah uang beredar dalam masyarakat cukup tinggi, maka terjadi peningkatan daya beli masyarakat. Peningkatan daya beli yang didukung oleh peningkatan penawaran produk akan memberikan tambahan pendapatan bagi perusahaan. Hal ini dikarenakan produk yang dihasilkan perusahaan dapat diserap penuh oleh pasar. Dengan meningkatnya pendapatan perusahaan maka perusahaan akan memiliki laba bersih yang ikut meningkat. Laba bersih yang mengalami peningkatan akan mendorong terjadinya peningkatan terhadap dividen yang akan dibagikan kepada para investor. Hal ini akan memancing investor untuk membeli saham perusahaan tersebut dengan maksud untuk memperoleh 


\section{JURNAL NOMINAL / VOLUME III NOMOR 2 / TAHUN 2014}

pembagian dividen. Tingginya permintaan terhadap saham akan mendorong terjadinya peningkatan harga saham. Harga saham yang meningkat akan mendorong peningkatan return ekspektasi investor sekaligus risiko sistematik saham yang harus ditanggung investor.(Nugroho, 2008)

\section{Debt to Equity Ratio dan Risiko} Sistematis

Salah satu proksi yang digunakan untuk mencerminkan financial leverage berpengaruh terhadap risiko sistematis adalah Debt to equity Ratio (DER). DER merupakan komponen rasio leverage. Rasio ini menunjukkan kekuatan perusahaan untuk memenuhi kewajiban jangka pendek dan jangka panjangnya. Debt to equity ratio menjelaskan hubungan perbandingan total hutang terhadap total modal sendiri. Variabel ini dirumuskan sebagai berikut :

DER $=\frac{\text { total hutang }}{\text { total modal sendiri }}$

(6)

Debt to equity ratio dapat memberikan gambaran mengenai struktur modal yang dimiliki perusahaan sehingga dapat diberikan gambaran risiko tidak tertagihnya hutang perusahaan. Semakin tinggi debt to equity ratio, maka risiko yang ditanggung investor akan semakin tinggi. Debt to equity ratio yang tinggi menunjukkan proporsi ekuitas yang rendah untuk membiayai aktiva. (Ang, 1997).

\section{Asset Growth dan Risiko Sistematis}

Variabel asset growth didefinisikan sebagai perubahan atau tingkat perubahan tahunan dari aktiva total. Asset Growth adalah rata-rata pertumbuhan kekayaan perusahaan. Bila kekayaan awal suatu perusahaan adalah tetap jumlahnya, maka pada tingkat pertumbuhan asset yang tinggi berarti besarnya kekayaan akhir perusahaan tersebut semakin besar, demikian pula sebaliknya.

Tingkat pertumbuhan asset yang cepat menunjukkan bahwa perusahaan sedang melakukan ekspansi. Apabila ekspansi ini mengalami kegagalan maka akan meningkatkan beban perusahaan untuk menutup pengembalian biaya ekspansi yang pada akhirnya akan menyebabkan nilai perusahaan itu menjadi kurang prospektif. Apabila kurang prospektif maka menyebabkan para investor menjual sahamnya di perusahaan tersebut karena minat dan harapan para pemodal turun. Hal ini menyebabkan perubahan return saham yang besar yang berakibat pada beta saham perusahaan yang besar. Asset Growth diprediksi akan mempunyai hubungan yang positif dengan beta 


\section{JURNAL NOMINAL / VOLUME III NOMOR 2 / TAHUN 2014}

saham. Asset growth menunjukkan pertumbuhan per tahun pemakian aktiva. Asset growth yang tinggi akan berimplikasi pada tingkat resiko yang tinggi pula. Hal ini dapat dijelaskan bahwa pemakaian aktiva yang tinggi akan memberikan tanggungan terhadap pengembalian investasi yang tinggi dan merupakan resiko yang tinggi apabila tidak dapat menutup pengembalian investasi tersebut. (Muljono, 2002).

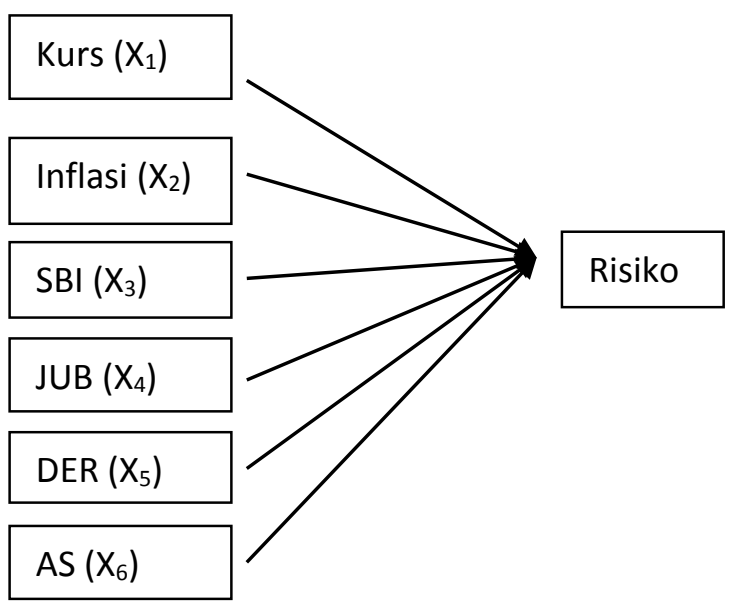

Gambar 2.1. Kerangka Teoritis

Hubungan Antara Tingkat Inflasi, Jumlah Uang Beredar, Tingkat Suku Bunga SBI, Debt to Equity dan Asset Growth terhadap Risiko Sistematis.

\section{METODE PENELITIAN}

\section{Ruang Lingkup Penelitian}

Penelitian ini ingin melihat pengaruh variabel-variabel makroekonomi yaitu kurs, inflasi, suku bunga SBI, jumlah uang beredar, debt to equity dan asset growth terhadap risiko sistematis saham pada perusahaan LQ-45. Penelitian ini termasuk ke dalam jenis penelitian kausalitas, penggolongan penelitian ditinjau dari sifat eksplanasi ilmu (Ferdinand, 2006). Eksplanasi ilmu adalah jenis penjelasan ilmu yang dihasilkan dari suatu penelitian. Sifat eksplanasi ilmu dapat dibedakan menjadi penelitian kausalitas dan penelitian kausalitas komparatif. Penelitian kausalitas merupakan penelitian yang ingin mencari penjelasan dalam bentuk hubungan sebab akibat antara beberapa konsep/variabel atau beberapa strategi yang dikembangkan manajemen. Penelitian ini mencari hubungan sebab akibat antara indikator-indikator faktor yang berpengaruh terhadap risiko sistematis pada perusahaan LQ-45.

\section{Jenis dan Sumber Data}

Jenis data penelitian termasuk ke dalam data kuantitatif dengan periode pengamatan dari tahun 2006 sampai tahun 2012. Sumber data yang digunakan dalam penelitian ini adalah data sekunder berupa data yang mendukung variabel penelitian. Data dari variabel eksogen penelitian ini, yaitu : tingkat inflasi, tingkat bunga SBI, kurs rupiah, Jumlah uang beredar, DER dan Asset Growth.

Data dari variabel endogen adalah risiko sistematis saham. Objek penelitian, yaitu Bursa Efek Indonesia. Periode penelitian dari tahun 2006 sampai tahun 2012. Data diperoleh dari informasi dan laporan dari 
Bursa Efek Indonesia, Bank Indonesia dan Biro Pusat Statistik.

\section{Populasi dan Sampel}

Di Bursa Efek Indonesia terdapat berbagai perusahaan go public dalam berbagai bidang usaha antara lain pertanian, pertambangan, industri dasar dan kimia, aneka industri, industri barang konsumsi, property dan real estate, infrastruktur, utilitas dan transportasi, keuangan, perdagangan, jasa dan investasi. Dari sejumlah saham yang terdaftar di Bursa Efek Indonesia, dipilih perusahaanperusahaan yang memenuhi kriteria ranking tinggi pada: (1) total transaksi, (2) nilai transaksi, dan (3) frekuensi transaksi. Saham-saham ini lalu dikumpulkan menjadi satu dan disebut sebagai LQ45. Pada penelitian ini perusahaan LQ45 dipilih sebagai populasi.

Pengambilan sampel dalam penelitian ini dilakukan secara purposive sampling berdasarkan kriteria-kriteria:

1. Perusahaan yang dijadikan sampel adalah perusahaan yang sahamnya masuk dalam indeks LQ-45 yang terdaftar di Bursa Efek Indonesia selama periode 2006 sampai 2012. Alasan mengapa diambilnya periode 2006 sampai dengan 2012 adalah karena pada tahun 2000 sampai dengan 2005 Indonesia sedang melakukan perbaikan dari krisis moneter yang melanda Indonesia pada tahun 1998 dan pada tahun tersebut kondisi ekonomi dalam keadaan stabil, sedangkan pada tahun 2006 terjadi gejolak bursa saham yang menyebabkan Indonesia terkena dampak yang cukup signifikan yang dilanjutkan dengan 2008 terjadi krisis global, 2010 dengan adanya krisis eropa. Hal ini menyebabkan harga saham berfluktuasi sehingga diambilnya periode 2006 sampai 2012.

2. Menerbitkan laporan keuangan selama periode 2006 sampai 2012.

3. Perusahaan yang menjadi sampel adalah perusahaan yang masuk dalam indeks LQ-45 minimal selama 6 kali selama periode 2006 sampai dengan 2012. Pemilihan sampel ini diambil karena risiko saham dapat dilihat dari perusahaan-perusahaan mempunyai perdagangan yang teraktif.

4. Perusahaan yang menjadi sampel adalah perusahaan yang tidak pernah melakukan stock split. Stock split merupakan salah satu cara perusahaan untuk meningkatkan perdagangan sahamnya dengan melakukan pemecahan saham sehingga harga saham menjadi rendah. Tujuan dari pemilihan sampel ini adalah jika perusahaan melakukan stock split maka harga saham perusahaan tersebut menjadi bias dan tidak bisa mencerminkan risiko yang ditanggung. 


\section{JURNAL NOMINAL / VOLUME III NOMOR 2 / TAHUN 2014}

Berdasarkan kriteria diatas, maka terdapat 30 perusahaan yang menjadi sampel penelitian yang memenuhi kriteria yang diatas.

\section{Metode Pengumpulan Data}

Metode pengumpulan data dengan menggunakan teknik dokumentasi yaitu teknik pengumpulan data yang dilakukan dengan cara mencatat data dari laporanlaporan yang ada dari beberapa sumber. Sumber tersebut dapat berupa informasi atau laporan dari Bursa Efek Indonesia, Bank Indonesia ataupun dari Biro Pusat Statistik. Data dari variabel kurs, inflasi, suku bunga SBI dan jumlah uang beredar yang akan diolah merupakan data bulanan dengan melakukan metode interpolasi linier, data dari variabel DER dan Asset Growth akan diambil dari laporan keuangan yang diterbitkan oleh perusahaan setiap tahunnya sedangkan risiko sistematis akan menggunakan perhitungan model indeks tunggal.

\section{Teknik Analisis Data}

Penelitian ini dilakukan dengan tujuan untuk mengetahui pengaruh hubungan antara variabel independen dan variabel dependen dengan skala pengukuran atau rasio dalam sebuah persamaan linier, oleh karena itu dalam penelitian ini digunakan analisis regresi linier berganda. Metode analisis dalam penelitian ini menggunakan data kuantitatif untuk memperkirakan secara kuantitatif dari variabel-variabel yang mempengaruhi, secara parsial maupun simultan terhadap beta saham. Alat bantu yang digunakan dalam penelitian ini adalah software komputer program SPSS 13.0 (Statistical Package for Social Science). Pengujian dilakukan dengan regresi berganda dengan model sebagai berikut :

$Y=b o+b_{1} X_{1}+b_{2} X_{2}+b_{3} X_{3}+b_{4} X_{4}+b_{5} X_{5}+b_{6} X_{6}+e$

Dimana :

$\mathrm{Y} \quad=$ Risiko sistematis

$\mathrm{X}_{1}=$ Kurs

$\mathrm{X}_{2}=$ Inflasi

$\mathrm{X}_{3} \quad=$ tingkat suku bunga

$\mathrm{X}_{4} \quad=$ jumlah uang beredar

$\mathrm{X}_{5} \quad=$ debt to equity (DER)

$\mathrm{X}_{6}=$ Asset Growth

$\mathrm{b}_{1}-\mathrm{b}_{6}=$ koefisien regresi dari tiap-tiap variabel independen

e $\quad=$ error term.

\section{Uji Asumsi Klasik}

\section{a. Pengujian Normalitas Data}

Menurut Ghozali (2011) uji normalitas bertujuan untuk menguji apakah dalam model regresi, variabel penggangu atau residual memiliki distribusi normal. Uji t dan uji $\mathrm{F}$ mengasumsikan bahwa nilai residual mengikuti distribusi normal. Kalau asumsi ini dilanggar maka uji statistic manjadi tidak valid untuk jumlah sampel yang kecil. Uji normalitas dilakukan dengan menggunakan Kolmogrov Smirnov Tes dengan ketentuan: 
1. Jika probabilitas $>0,05$ maka data jika berbeda disebut heteroskedastisitas berdistribusi normal

(Ghozali, 2011). Model regresi yang baik

2. Jika probabilitas $<0,05$ maka data tidak berdistribusi nol

jika tidak terjadi heteroskedastisitas. Dalam penelitian ini untuk menguji

\section{b. Pengujian Multikolinieritas}

Menurut Ghozali (2011) multikolinieritas bertujuan untuk menguji apakah model regresi ditemukan adanya korelasi antar variabel bebas (independen). Untuk menguji asumsi multikolonieritas digunakan VIF (Variance Inflation Factor). Dasar pengambilan keputusan:

1.) Besarnya VIF dan tolerance

a) Mempunyai nilai VIF disekitar angka 1

b) Mempunyai nilai tolerance mendekati 1

heteroskedastisitas dengan menggunakan uji park. Uji park mengemukakan metode bahwa variance $\left(S^{2}\right)$ merupakan fungsi dari variabel-variabel independen. Dasar analisis dalam uji park, apabila koefisien parameter untuk variabel independen dari persamaan regresi signifikan secara statistik hal ini menunjukkan bahwa dalam data model empiris yang diestimasi terdapat heteroskedastisitas dan sebaliknya jika parameter untuk variabel independen tidak signifikan secara statistik maka asumsi homoskedastisitas pada model tidak dapat ditolak.

2.) Besarnya korelasi antarvariabel independen

Koefisien korelasi antarvariabel independen haruslah lemah (dibawah 0,5) jika korelasi kuat maka terjadi problem multikolinieralitas.

\section{c. Pengujian Heteroskedastisitas}

Heteroskedastisitas adalah suatu situasi yang menunjukkan setiap residual yang dibatasi oleh nilai tertentu merupakan nilai varians konstan. Uji heteroskedastisitas bertujuan menguji apakah dalam model regresi terjadi ketidaksamaan varians dari residual satu pengamatan ke pengamatan lain tetap, yang dapat disebut sebagai homoskedastisitas dan

\section{d. Pengujian Hipotesis Statistik}

Pengujian hipotesis dilakukan dengan memperhatikan dua pengujian, yaitu uji parsial (uji t) dan uji Anova (uji F).

a. Uji Parsial (uji t)

Untuk mengetahui seberapa besar pengaruh variabel independen secara individu diukur dengan menggunakan uji t statistik. Uji $\mathrm{t}$ adalah uji yang digunakan untuk menguji hubungan regresi secara parsial. Pengujian ini dilakukan untuk mengukur tingkat signifikasi setiap variabel bebas terhadap variabel terikat. Pengaruh hipotesis terhadap koefisien regresi 
secara parsial menggunakan uji t pada tingkat kesalahan $\alpha$. Dasar pengambilan keputusan dengan melihat tingkat probabilitas.

Jika probabilitas < 0,05: $\mathrm{H}_{0}$ ditolak Jika probabilitas > 0,05: $\mathrm{H}_{0}$ diterima

b. Uji anova (uji F)

Untuk mengetahui seberapa besar pengaruh variabel independen terhadap variabel dependen. Uji $\mathrm{F}$ adalah uji yang dilakukan untuk membuktikan pengaruh variabelvariabel bebas secara keseluruhan terhadap variabel terikat pada analisis regresi. Pengujian dilakukan pada uji $\mathrm{F}$ dengan tingkat keyakinan $95 \%$. Dasar pengambilan keputusan dengan melihat tingkat probabilitas.

Jika probabilitas $<0.05: \mathrm{H}_{0}$ ditolak dan Ha diterima

Jika probabilitas $>0.05: \mathrm{H}_{0}$ diterima dan Ha ditolak

c. Koefisien Determinasi $\left(\mathrm{R}^{2}\right)$

Koefisien determinasi $\left(\mathrm{R}^{2}\right)$ pada dasarnya mengukur seberapa jauh kemampuan model dalam menerangkan variabel dependen. Nilai koefisien determinasi adalah diantara nol dan satu. Nilai $R^{2}$ yang kecil memperlihatkan kemampuan variabel independen dalam menjelaskan variabel-variabel sangat terbatas. Nilai yang mendekati satu berarti variabel-variabel independen memberikan hampir semua informasi yang dierlukan untuk memprediksikan variabel-variabel dependen. Tetapi penggunaan koefisien determinasi tersebut memiliki suatu kelemahan, yaitu terdapatnya suatu bias terhadap jumlah variabel independen yang dimasukkan kedalam model. Agar terhindar dari bias tersebut, maka digunakan nilai adjusted $\mathrm{R}^{2}$, dimana nilai adjusted $\mathrm{R}^{2}$ mampu naik atau turun apabila terjadi penambahan satu variabel independen (Ghozali, 2011).

\section{HASIL PENELITIAN DAN} PEMBAHASAN

\section{Statistik Dekriptif}

Analisis deskriptif adalah analisis yang menggambarkan suatu data yang akan dibuat baik sendiri maupun secara kelompok. Tujuan analisis deskriptif untuk membuat gambaran secara sistematis data yang faktual dan akurat mengenai fakta-fakta serta hubungan antar fenomena yang diselidiki atau diteliti.

Berdasarkan hasil yang diperoleh dengan melakukan pengujian statisktik deskriptif dapat diketahui karakteristik data penelitian yang digunakan. Statistik deskriptif untuk masing-masing variabel, yaitu inflasi, kurs, tingkat suku bunga BI, jumlah uang beredar, 


\section{JURNAL NOMINAL / VOLUME III NOMOR 2 / TAHUN 2014}

DER, asset growth dan risiko sistematis saham (beta) disajikan dalam Tabel 4.1.

Tabel 4.1. Statistik Deskriptif

\begin{tabular}{|c|c|c|c|c|c|}
\hline $\begin{array}{l}\text { Ketera } \\
\text { ngan }\end{array}$ & $\mathrm{N}$ & $\begin{array}{l}\text { Mini } \\
\text { mum }\end{array}$ & $\begin{array}{l}\text { Maksi } \\
\text { mum }\end{array}$ & $\begin{array}{l}\mathrm{Me} \\
\text { an }\end{array}$ & $\begin{array}{l}\text { Std. } \\
\text { Devi } \\
\text { ation }\end{array}$ \\
\hline \multirow[t]{3}{*}{ Beta } & 1 & $-3,24$ & 3,59 & - & 1,063 \\
\hline & 7 & & & 0,0 & 02 \\
\hline & 1 & & & 077 & \\
\hline \multirow[t]{3}{*}{ Inflasi } & 1 & $-0,96$ & 1,11 & - & 0,606 \\
\hline & 7 & & & 0,0 & 90 \\
\hline & 1 & & & 010 & \\
\hline \multirow[t]{3}{*}{ Kurs } & 1 & $-0,17$ & 0,13 & 0,0 & 0,071 \\
\hline & 7 & & & 002 & 46 \\
\hline & 1 & & & & \\
\hline \multirow[t]{3}{*}{ JUB } & 1 & $-0,88$ & 0,71 & 0,0 & 0,362 \\
\hline & 7 & & & 019 & 09 \\
\hline & 1 & & & & \\
\hline \multirow[t]{3}{*}{ DER } & 1 & $-2,92$ & 2,84 & 0,0 & 0,655 \\
\hline & 7 & & & 085 & 56 \\
\hline & 1 & & & & \\
\hline \multirow[t]{3}{*}{ AS } & 1 & $-08,7$ & 8,96 & 0,0 & 1,056 \\
\hline & 7 & & & 008 & 70 \\
\hline & 1 & & & & \\
\hline
\end{tabular}

Sumber : data diolah

Berdasarkan data pada tabel di atas, terlihat jumlah data penelitian sebanyak 171 data yang dikumpulkan per tahun selama 7 tahun dari tahun 2006 sampai tahun 2012. Beta saham memiliki nilai minimum sebesar 3,24, nilai maksimum sebesar 3,59, mean sebesar -0,0077 dan deviasi standar sebesar
1,06302. Tingkat inflasi memiliki nilai minimum sebesar $-0,96 \%$, nilai maksimum sebesar $1,11 \%$, mean sebesar $-0,001 \%$ dan deviasi standar sebesar $0,60690 \%$. Kurs memiliki nilai minimum sebesar $-0,17$, nilai maksimum sebesar 0,13 , mean sebesar 0,0002 dan deviasi standar sebesar 0,07146. Jumlah uang beredar memiliki nilai minimum sebesar $-0,88$, nilai maksimum sebesar 0,71, mean sebesar 0,0019 dan deviasi standar sebesar 0,36209. Debt to equity memiliki nilai minimum sebesar 2,92, nilai maksimum sebesar 2,84, mean sebesar 0,0085 dan deviasi standar sebesar 0,65556. Asset growth memiliki nilai minimum sebesar $-8,7$, nilai maksimum sebesar 8,96, mean sebesar 0,0008 dan deviasi standar sebesar 1,05670.

\section{Uji Asumsi Klasik}

\section{a. Pengujian Normalitas Data}

Uji normalitas bertujuan untuk menguji apakah dalam model regresi, variabel pengganggu atau residual memiliki distribusi normal. Uji statistik yang digunakan untuk menguji normalitas residual adalah uji statistik nonparametrik Kolmogorov-Smirnof (K-S). Dalam melakukan pengujian normalitas terjadi masalah data tidak berdistribusi secara normal maka perlu dilakukanya transformasi data dengan menggunakan logaritma natural. Hasil pengujian setelah dilakukannya tranformasi data tetap data tidak berdistribusi secara 
normal sehingga data outlier perlu dikeluarkan. Hasil pengujian menyatakan bahwa data berdistribusi secara normal setelah data outlier dikelaurkan sebanyak 47 data. Berikut ini hasil pengujian normalitas dengan menggunakan Kolmogorof-Smirnof (K-S).

Tabel 4.2. Hasil Uji Normalitas

\begin{tabular}{lll}
\hline Keterangan & $\begin{array}{l}\text { Kolmogorov- } \\
\text { Smirnof }(\mathrm{K}-\mathrm{S})\end{array}$ & Signifikansi \\
& 1,287 & 0,073
\end{tabular}

Sumber : data diolah

Berdasarkan Tabel 4.2, nilai signifikansi sebesar 1,287 atau probabilitas diatas 5\% $(0,073>0,05)$. Maka dapat disimpulkan data residual berdistribusi normal.

\section{b. Pengujian Multikolinearitas}

Uji multikolinieritas bertujuan untuk menguji apakah model regresi ditemukan adanya korelasi antar variabel bebas (independen). Untuk menguji asumsi multikolonieritas digunakan VIF (Variance Inflation Factor) dan nilai tolerance. Dasar pengambilan keputusan adalah variabel eksogen mempunyai nilai VIF disekitar angka 1 dan mempunyai nilai tolerance mendekati 1. Dalam melakukan pengujian multikolinearitas terjadi masalah multikolinearitas maka diperlukannya transformasi data dengan menggunakan logaritma natural. Hasil pengujian setelah dilakukannya tranformasi data tetap terjadi multikolinearitas sehingga data outlier perlu dikeluarkan.

Hasil pengujian setelah data outlier dikeluarkan teryata masih menunjukkan terjadinya multikolinearitas sehingga perlu mengeluarkan variabel yang memiliki kolerasi yang tinggi yaitu tingkat suku bunga BI. Setelah dikeluarkan variabel tingkat suku bunga BI hasil pengujian dinyatakan tidak terjadi multikolinearitas. Berikut ini hasil pengujian multikolinearitas setelah dikeluarkannya variabel tingkat suku bunga. Hasil pengujian multikolinieritas pada substruktur 1 terlihat pada Tabel 4.3.

Tabel 4.3. Hasil Uji Multikoliearitas

\begin{tabular}{lll}
\hline Variabel & Tolerance & VIF \\
\hline DIFF & 0,472 & 2,117 \\
(ln_inflasi,1) & & \\
\hline DIFF (ln_kurs,1) & 0,936 & 1,068 \\
\hline DIFF (ln_jub,1) & 0,487 & 2,052 \\
\hline DIFF (ln_der,1) & 0,977 & 1,024 \\
\hline DIFF (ln_AS,1) & 0,938 & 1,066
\end{tabular}

Sumber: data diolah

Pada Tabel 4.3 terlihat nilai Tolerance untuk semua variabel eksogen mendekati angka 1 dan nilai VIF berada disekitar angka 1 sehingga dapat disimpulkan bahwa tidak terjadi masalah multikolinieritas. 


\section{c. Pengujian Heterokedastisitas}

Uji heteroskedastisitas bertujuan untuk menguji apakah dalam model regresi terjadi ketidaksamaan variance dari residual suatu pengamatan ke pengamatan yang lain. Model regresi yang baik adalah homoskedastisitas atau tidak terjadi heteroskedastisitas. Dalam model ini untuk menguji heteroskedastisitas menggunakan uji park.

Tabel 4.4. Hasil Uji Heterokedastisitas

\begin{tabular}{lll}
\hline Variabel & T-test & Signifikansi \\
\hline DIFF(ln_inf,1) & $-0,109$ & 0,913 \\
\hline DIFF(ln_kurs, 1) & 0,537 & 0,592 \\
\hline DIFF(ln_JUB,1) & $-1,486$ & 0,139 \\
\hline DIFF(ln_DER,1) & 1,729 & 0,086 \\
\hline DIFF(ln_AS,1) & 1,342 & 0,181
\end{tabular}

Sumber : data diolah

Tabel 4.4 di atas menunjukkan nilai koefisien parameter untuk variabel eksogen memiliki tingkat signifikan di atas $5 \%$ atau 0,05. Variabel independen baik DIFF(ln_infl,1), $\quad$ DIFF(ln_kurs, 1$)$, DIFF(ln_JUB, 1), DIFF(ln_DER,1), dan DIFF(ln_AS,1) memiliki tingkat signifikan di atas 0,05 atau signifikan pada tingkat 5\%, hal ini berarti model regresi tidak terdapat heteroskedastisitas.

\section{Hasil Persamaan Regresi}

Penelitian ini menggunakan analisis regresi berganda dengan bantuan program SPSS versi 13.0. Dari tabel 4.5 persamaan regresi sebagai berikut:

$\begin{array}{ccr}Y=-0,005-0,163 \text { DIFF }\left(\ln \_ \text {infl, } 1\right) & +2,154 \\ \text { DIFF(ln_kurs, } 1) & - & 0,369 \\ \text { DIFF(ln_JUB,1) } & - & 0,276 \\ \text { DIFF(ln_DER,1) } & + & 0,220 \\ \text { DIFF(ln_AS,1) } & & \end{array}$

Tabel 4.5. Hasil Persamaan Regresi

\begin{tabular}{|c|c|c|c|c|}
\hline Model & $\begin{array}{l}\text { Uns } \\
\text { zed } \\
\text { Coe }\end{array}$ & $\begin{array}{l}\text { Indardi } \\
\text { cients }\end{array}$ & & \\
\hline & B & $\begin{array}{l}\text { Std.er } \\
\text { ror }\end{array}$ & $\mathrm{T}$ & $\begin{array}{l}\text { Signifik } \\
\text { ansi }\end{array}$ \\
\hline (Contants) & $\begin{array}{l}- \\
0,0 \\
05\end{array}$ & 0,078 & $\begin{array}{l}- \\
0,0 \\
70\end{array}$ & 0,944 \\
\hline $\begin{array}{l}\text { DIFF(ln_inf } \\
1,1)\end{array}$ & $\begin{array}{l}- \\
0,1 \\
63\end{array}$ & 0,187 & $\begin{array}{l}- \\
0,8 \\
70\end{array}$ & 0,385 \\
\hline
\end{tabular}

\begin{tabular}{lllll} 
DIFF(ln_ku & 2,1 & 1,131 & 1,9 & 0,059 \\
rs,1) & 54 & & 05 & \\
\hline DIFF(ln_JU & - & 0,309 & - & 0,234 \\
B,1) & 0,3 & & 1,1 & \\
& 69 & & 94 &
\end{tabular}

\begin{tabular}{|c|c|c|c|c|}
\hline DIFF(ln_D & - & 0,121 & - & 0,024 \\
\hline \multirow[t]{2}{*}{$\mathrm{ER}, 1)$} & 0,2 & & 2,2 & \\
\hline & 76 & & 85 & \\
\hline DIFF(ln_AS & 0,2 & 0,076 & 2,8 & 0,005 \\
\hline ,1) & 20 & & 77 & \\
\hline
\end{tabular}

Sumber : data diolah

Hasil persamaan regresi menunjukkan bahwa variabel inflasi, jumlah uang beredar, debt to 


\section{JURNAL NOMINAL / VOLUME III NOMOR 2 / TAHUN 2014}

equity mempunyai hubungan yang negatif/berlawanan dengan risiko sistematis saham. Sedangkan kurs dan asset growth mempunyai hubungan positif dengan risiko sistematis saham. Kontanta sebesar $-0,005$ menyatakan bahwa jika tidak ada variabel inflasi, kurs, JUB, DER dan Asset growth maka risiko sistematis saham sebesar $-0,005$. Koefisien inflasi sebesar $-0,163$ menunjukkan bahwa setiap penambahan/kenaikan $1 \%$ tingkat inflasi akan menurunkan beta saham sebesar 0,163. Koefisien kurs sebesar 2,154 menunjukkan bahwa setiap penambahan/kenaikan Rp. 1 kurs maka akan meningkatkan beta saham sebesar 2,154. Koefisien jumlah uang beredar sebesar -0,369 menunjukkan bahwa setiap penambahan/kenaikan Rp.1 jumlah uang beredar maka akan menurunkan beta saham sebesar 0,369. Koefisien debt to equity sebesar -0,276 menunjukkan bahwa setiap penambahan/kenaikan $1 \%$ DER maka akan menurunkan beta saham sebesar 0,276. Demikian juga dengan koefisien dari asset growth sebesar 0,220 menunjukkan bahwa setiap penambahan/kenaikan 1 asset growth akan meningkatkan beta saham sebesar 0,220 .

\section{Pengujian Hipotesis}

Pengujian hipotesis dalam penelitian ini dillakukan secara parsial dan simultan. Pengujian hipotesis secara parsial dilakukan dengan uji t, sedangkan hipotesis secara

Tabel 4.6. Hasil Uji F

\begin{tabular}{lll}
\hline Keterangan & F & Signifikansi \\
\hline Residual & 3,970 & 0,002
\end{tabular}

Sumber : data diolah

Berdasarkan hasil pengujian uji $\mathrm{F}$ maka dapat disimpulkan ada pengaruh yang signifikan antara variabel-variabel inflasi, kurs, jumlah uang beredar, debt to equity dan asset growth terhadap risiko sistematis saham pada perusahaan LQ-45.

\section{Hipotesis Kedua}

Hipotesis kedua dalam penelitian ini menggunakan uji t. Uji t ini dapat dilihat dari harga t-tabel dan nilai signifikansi. Harga ttabel untuk df dengan jumlah sampel 171 
adalah 1,9739.Dari tabel 4.7. didapat dari uji $\mathrm{t}:$

Tabel 4.7. Hasil Uji t

\begin{tabular}{|c|c|c|c|}
\hline Variabel & $\begin{array}{l}\text { Standardi } \\
\text { zed } \\
\text { Coefficie } \\
\text { nts Beta }\end{array}$ & $\begin{array}{l}\text { t_te } \\
\text { st }\end{array}$ & $\begin{array}{l}\text { Signifika } \\
\text { nsi }\end{array}$ \\
\hline $\begin{array}{l}\text { DIFF(ln_infl, } \\
\text { 1) }\end{array}$ & $-0,093$ & $\begin{array}{l}- \\
0,87 \\
0\end{array}$ & 0,385 \\
\hline $\begin{array}{l}\text { DIFF(ln_kurs } \\
, 1)\end{array}$ & 0,145 & $\begin{array}{l}1,90 \\
5\end{array}$ & 0,059 \\
\hline $\begin{array}{l}\text { DIFF(ln_JU } \\
\mathrm{B}, 1)\end{array}$ & $-1,194$ & $\begin{array}{l}- \\
1,19 \\
4\end{array}$ & 0,234 \\
\hline $\begin{array}{l}\text { DIFF(ln_DE } \\
\mathrm{R}, 1)\end{array}$ & $-0,17$ & $\begin{array}{l}- \\
2,28 \\
5\end{array}$ & 0,024 \\
\hline $\begin{array}{l}\mathrm{DIFF}\left(\mathrm{ln} \_\mathrm{AS},\right. \\
\text { 1) }\end{array}$ & 0,218 & $\begin{array}{l}2,87 \\
7\end{array}$ & 0,005 \\
\hline
\end{tabular}

Sumber: data diolah

a. Dari tabel 4.8. diatas didapat t-hitung dari variabel inflasi adalah 0,87 . Jadi t-hitung $\quad 0,87<1,9739 \quad$ kemudian pengujian ini juga bisa dilihat dari tingkat signifikansi. Pada tabel 4.8. didapat tingkat signifikansi 0,385 yang teryata lebih besar dari 0,05 . Berdasarkan hasil pengujian yang didapat disimpulkan bahwa inflasi tidak berpengaruh secara signifikan terhadap risiko sistematis saham.

b. Dari tabel 4.8. diatas didapat t-hitung dari variabel kurs adalah 1,905. Jadi t-hitung $\quad 1,905<1,9739$ kemudian pengujian ini juga bisa dilihat dari tingkat signifikansi. Pada tabel 4.8. didapat tingkat signifikansi 0,059 yang teryata lebih besar dari 0,05 . Berdasarkan hasil pengujian yang didapat disimpulkan bahwa kurs tidak berpengaruh secara signifikan terhadap risiko sistematis saham.

c. Dari tabel 4.8. diatas didapat t-hitung dari variabel jumlah uang beredar adalah 1,194. Jadi t-hitung $1,194<1,9739$ kemudian pengujian ini juga bisa dilihat dari tingkat signifikansi. Pada tabel 4.8. didapat tingkat signifikansi 0,234 yang teryata lebih besar dari 0,05. Berdasarkan hasil pengujian yang didapat disimpulkan bahwa jumlah uang beredar tidak berpengaruh secara signifikan terhadap risiko sistematis saham.

d. Dari tabel 4.8. diatas didapat t-hitung dari variabel debt to equity adalah 2,285. Jadi t-hitung 2,285<1,9739 kemudian pengujian ini juga bisa dilihat dari tingkat signifikansi. Pada tabel 4.8. didapat tingkat signifikansi 0,024 yang teryata lebih kecil dari 0,05 . Berdasarkan hasil pengujian 
yang didapat disimpulkan bahwa debt to equity (DER) berpengaruh secara signifikan terhadap risiko sistematis saham.

e. Dari tabel 4.8. diatas didapat t-hitung dari variabel asset growth adalah 2,877. Jadi t-hitung $2,877<1,9739$ kemudian pengujian ini juga bisa dilihat dari tingkat signifikansi. Pada tabel 4.8. didapat tingkat signifikansi 0,005 yang teryata lebih kecil dari 0,05 . Berdasarkan hasil pengujian yang didapat disimpulkan bahwa asset growth berpengaruh secara signifikan terhadap risiko sistematis saham.

\section{Koefisien Determinasi}

Koefisien determinasi $\left(\mathrm{R}^{2}\right)$ pada dasarnya mengukur seberapa jauh kemampuan model dalam menerangkan variabel dependen. Nilai koefisien determinasi adalah diantara nol dan satu. Nilai $\mathrm{R}^{2}$ yang kecil memperlihatkan kemampuan variabel independen dalam menjelaskan variabel-variabel sangat terbatas. Nilai yang mendekati satu berarti variabel-variabel independen memberikan hampir semua informasi yang dierlukan untuk memprediksikan variabel-variabel dependen. Tetapi penggunaan koefisien determinasi tersebut memiliki suatu kelemahan, yaitu terdapatnya suatu bias terhadap jumlah variabel independen yang dimasukkan kedalam model. Agar terhindar

dari bias tersebut, maka digunakan nilai adjusted $\mathrm{R}^{2}$, dimana nilai adjusted $\mathrm{R}^{2}$ mampu naik atau turun apabila terjadi penambahan satu variabel independent. Hasil dari koefisien determinasi :

Tabel 4.8. Hasil Koefisien Determinasi

\begin{tabular}{ll} 
Model & $\mathrm{R}^{2}$ \\
\hline 1 & 0,054
\end{tabular}

Sumber : data diolah

Pada tabel 4.8. didapat nilai $\mathrm{R}^{2}$ sebesar 0,054 yang menjelaskan bahwa sebesar 5,4\% variasi dari beta saham dijelaskan oleh variabel inflasi, kurs, jumlah uang beredar, debt to equity dan asset growth, sedangkan sisanya sebesar 94,6\% dijelaskan oleh faktor diluar model.

\section{Analisis Ekonomi}

Perkembangan pasar modal sangat dipengaruhi oleh kondisi perekonomian suatu negara termasuk Indonesia perkembangan pasar modal Indonesia dipengaruhi oleh kondisi perekonomian Indonesia. Jika kondisi perekonomian Indonesia dalam kondisi stabil maka perkembangan pasar modal menunjukkan prospek yang baik. Hal ini tercermin dari perkembangan indeks harga saham gabungan (IHSG) yang ada di bursa efek. Perkembangan indeks harga saham gabungan (IHSG) sangat tergantung dari 


\section{JURNAL NOMINAL / VOLUME III NOMOR 2 / TAHUN 2014}

ketertarikan para investor dalam menginvestasikan modalnya di saham, dimana semakin banyak investor menanamkan modalnya di pasar modal maka harga saham akan semakin tinggi sehingga indeks harga saham gabungan (IHSG) yang dihasilkan juga mengalami kenaikan.

Sebelum melakukan investasi di pasar modal para investor seharusnya melakukan analisis ekonomi karena analisis ekonomi merupakan analisis berbagai indikator yang biasanya digunakan oleh pengambil kebijakan dalam bidang perekonomian seperti tingkat inflasi, kurs,tingkat suku bunga SBI, dan berbagai indikator perekonomian lainnya. Karena perekonomian yang baik secara umum menunjukkan tingkat perbaikan kesejateraan masyarakat yang biasanya diikuti dengan peningkatan kegiatan pasar modal. Dengan perekonomian yang baik maka risiko yang ditanggung oleh investor akan kecil. Dalam melakukan investasi kecenderungan investor menginginkan tingkat pengembalian yang tinggi dengan risiko yang rendah, tetapi pada kenyataannya tingkat pengembalian yang tinggi akan juga meningkatkan risiko yang harus ditanggung oleh investor.

Dalam pengujian ini ada 1 variabel makro yang dibuang karena adanya kolerasi yang kuat dengan variabel lain khususnya inflasi dan jumlah uang beredar. Berdasarkan teori yang ada memang ada kolerasi antara inflasi dan tingkat bunga BI. Menurut
Suardana (2006) suku bunga merupakan alat untuk menekan inflasi. Dengan naiknya suku bunga diharapkan pemilik uang akan menabungkan uangnya di bank. Uang akan masuk ke dalam kas bank umum. Hal itu berarti jumlah uang yang beredar akan berkurang. Berkurangnya jumlah uang yang beredar akan dapat meredakan inflasi.

Inflasi merupakan kenaikan hargaharga secara umum dan berlangsung terus menerus untuk jangka waktu tertentu. Umumnya inflasi terjadi karena masyarakat terlalu konsumtif sehingga terjadi kelangkaan. Apabila terjadi inflasi yang terlalu tinggi maka menyebabkan daya beli masyarakat menurun, untuk mengatasi hal ini pemerintah akan mengeluarkan kebijakan moneter. Kebijakan moneter yang paling umum dikeluarkan oleh pemerintah untuk mengatasi inflasi adalah dengan meningkatkan suku bunga. Peningkatan suku bunga ini bertujuan untuk menarik minat masyarakat untuk berinvestasi pada tabungan, deposito, maupun SBI. Dengan demikian diharapkan kebiasaan konsumtif masyarakat dapat menurun dan inflasi kembali stabil.

Peningkatan suku bunga yang terlalu tinggi juga dapat memberikan dampak buruk bagi perekonomian suatu negara. Apabila suku bunga terlalu tinggi maka masyarakat akan cenderung menginvestasikan uangnya pada bank daripada melakukan kegiatan ekonomi. Hal ini akan menyebabkan 


\section{JURNAL NOMINAL / VOLUME III NOMOR 2 / TAHUN 2014}

terjadinya deflasi atau penurunan hargaharga secara umum. Deflasi akan mengakibatkan pertumbuhan ekonomi menjadi lambat dan tidak mampu menarik minat investor untuk berinvestasi. Dengan demikian terdapat hubungan yang saling mempengaruhi antara inflasi dan suku bunga SBI dan merupakan hubungan yang positif.

Sedangkan adanya hubungan antara tingkat bunga SBI dan jumlah uang beredar sesuai dengan teori dan penelitian yang dilakukan oleh Paul dan Maurice (2005) dimana kenaikan tingkat penawaran uang akan menurunkan suku bunga, sedangkan penurunan tingkat penawaran uang akan meningkatkan suku bunga. Apabila suku bunga SBI mengalami peningkatan maka masyarakat akan cenderung melakukan investasi daripada kegiatan konsumtif. Kegiatan investasi yang dilakukan masyarakat pada SBI akan menurunkan jumlah uang beredar yang ada didalam suatu negara.

Jumlah uang beredar juga dapat mempengaruhi suku bunga Sertifikat Bank Indonesia. Apabila pemerintah menilai bahwa jumlah uang beredar yang ada di masyarakat terlalu sedikit untuk menggerakkan perekonomian, maka pemerintah akan mengeluarkan kebijakan moneter. Salah satu kebijakan moneter adalah menurunkan suku bunga. Penurunan suku bunga ini akan dialami oleh hampir seluruh produk perbankan baik tabungan, deposito, maupun SBI. Penurunan suku bunga SBI ini akan menurunkan minat masyarakat untuk berinvestasi pada SBI dan pada akhirnya jumlah uang beredar kembali meningkat.

Setelah dibuangnya 1 variabel makro yaitu tingkat suku bunga SBI maka diperoleh bahwa inflasi, kurs dan jumlah uang beredar tidak berpengaruh secara signifikan terhadap beta saham sedangkan variabel mikro yaitu debt to equity dan asset growth berpengaruh secara signifikan terhadap beta saham. Hasil yang diperoleh berbeda dengan penelitian sebelumnya. Makaryanawati dan Ulum (2008) menemukan bahwa tingkat suku bunga berpengaruh secara signifikan terhadap beta saham sedangkan tingkat likuiditas tidak berpengaruh terhadap beta saham. Haryanto dan Riyatno (2007) menemukan bahwa kurs dan tingkat bunga SBi berpengaruh terhadap beta saham. Ocran (2010) menemukan bahwa perekonomian makro di Ghana tidak berpengaruh terhadap beta saham. Hamzah (2005) menemukan bahwa kurs dan PBD berpengaruh terhadap beta saham.

Dalam penelitian ini variabel makro yang diwakili oleh inflasi, kurs, dan jumlah uang yang beredar tidak signifikan berpengaruh terhadap risiko sistematis saham dikarenakan investor Indonesia tidak menyukai risiko dalam berinvestasi. Ketika adanya kenaikan inflasi, kurs dan jumlah uang beredar cenderung investor tidak 


\section{JURNAL NOMINAL / VOLUME III NOMOR 2 / TAHUN 2014}

tertarik berinvestasi di pasar modal karena risiko yang harus ditanggung oleh investor juga tinggi. Hasil penelitian ini sejalan dengan penelitian yang dilakukan oleh Tandelilin (1997) dimana variabel makro tidak berpengaruh terhadap beta saham dikarenakan periode, sampel yang diambil dan kondisi ekonomi yang sedang stabil.

Dalam berinvestasi selain melihat dari sisi makro investor juga harus melihat dari sisi mikro perusahaan, karena ketika kondisi perusahaan dalam kondisi yang tidak baik maka akan meningkatkan risiko yang harus ditanggung oleh investor. Dalam penelitian ini variabel mikro yang diambil diwakili oleh debt to equity dan asset growth dimana hasil yang didapat bahwa debt to equity dan asset growth berpengaruh terhadap risiko sistematis saham. Hasil penelitian ini memiliki koefisien sebesar $27,6 \%$ dimana angka ini relatif kecil debt to equity berpengaruh signifikan dengan arah yang negatif terhadap risiko sistematis saham. Penelitian ini berbeda dengan penelitian sebelumnya dimana debt to equity berpengaruh positif terhadap beta saham.

Dalam penelitian ini didapat bahwa debt to equity memiliki hubungan yang negatif dan berpengaruh signifikan terhadap beta saham. Debt to equity menunjukkan kemampuan perusahaan untuk memenuhi kewajiban jangka panjang dan pendeknya. Menurut Komariah, Julenah dan Chuderi (2011) dimana pendanaan dapat meningkatkan nilai perusahaan. Apabila pendanaan didanai melalui hutang peningkatkan tersebut terjadi akibat dari efek tax deductible, artinya perusahaan yang memiiki hutang akan membayar bunga pinjaman yang dapat mengurangi penghasilan kena pajak dan dapat memberi manfaat bagi pemegang saham. Selain itu, penggunaan dana ekstenal akan menambah pendapatan perusahaan yang nantinya akan digunakan untuk kegiatan investasi yang menguntungkkan bagi perusahaan. Sehingga dapat dikatakan bahwa debt to equity berpengaruh signifikan dengan arah yang negatif terhadap risiko sistematis saham dimana jika debt to equity meningkat $1 \%$ maka akan menurunkan risiko sistematis sebesar 0,27 atau 27\%. Koefisien ini relatif kecil karena seharusnya debt to equity berpengaruh positif terhadap risiko sistematis, dimana rasio DER tinggi maka akan meningkatkan risiko yang ditanggung oleh investor. Hal ini juga bisa dilihat dari trend data dan berhubungan dengan kondisi ekonomi yang ada. Dari trend data pada tahun 2008 pada saat kondisi ekonomi sedang tidak stabil. Dimana pada tahun tersebut terjadi krisis global dan trend data rasio DER perusahaan meningkat.

Asset growth menunjukkan rata-rata pertumbuhan kekayaan perusahaan, dimana kemampuan perusahaan dalam mengolah asset perusahaan. dalam penelitian ini menunjukkan sebesar $22 \%$ asset growth berpengaruh terhadap beta saham. Koefisien 


\section{JURNAL NOMINAL / VOLUME III NOMOR 2 / TAHUN 2014}

asset growth ini relatif kecil, dikarenakan pertumbuhan asset yang tinggi akan menbuat investor percaya terhadap perusahaan dalam mengembangkan bisnisnya tetapi dalam penelitin ini dihasilkan asset growt memiliki hubungan yang positif terhadap beta saham. Koefisien asset growth ini relatif kecil. Hal ini sejalan dengan teori yang ada,dimana asset growth yang tinggi akan berimplikasi pada tingkat resiko yang tinggi pula. Hal ini dapat dijelaskan bahwa pemakaian aktiva yang tinggi akan memberikan tanggungan terhadap pengembalian investasi yang tinggi dan merupakan resiko yang tinggi apabila tidak dapat menutup pengembalian investasi tersebut. (Muljono, 2002).

Tingkat pertumbuhan asset yang cepat menunjukkan bahwa perusahaan sedang melakukan ekspansi. Dalam melakukan ekspansi perusahaan harus menanggung 2 risiko yaitu ekspansi yang dilakukan berhasil dan ekspansi yang dilakukan tidak berhasil. Jika ekspansi yang dilakukan berhasil maka perusahaan akan tetap bertahan sedangkan jika ekspansi yang dilakukan gagal maka akan meningkatkan biaya perusahaan yang tinggi dan berakibat kepada risiko yang harus ditanggung oleh investor juga tinggi. hasil pengujian ini didukung oleh penelitian yang dilakukan oleh Tandelilin (1997) dimana variabel mikro perusahaan (faktor fundamental) berpengaruh terhadap risiko sistematis saham.

\section{SIMPULAN DAN SARAN}

Berdasarkan hasil analisis dan pembahasan yang telah dikemukakan sebelumnya, maka penelitian ini mengambil beberapa simpulan yang ditujukan untuk menjawab permasalahan, simpulan dari penelitian ini yaitu :

1. Tingkat inflasi, kurs, jumlah uang beredar, DER dan asset growth berpengaruh secara serentak terhadap risiko sistematis saham.

2. Tingkat inflasi, kurs, dan jumlah uang beredar tidak berpengaruh terhadap risiko sistematis saham sedangkan DER dan asset growth berpengaruh terhadap risiko sistematis saham. Dapat disimpulkan bahwa variabel makro yang diatur oleh kebijakan pemerintah tidak bepengaruh terhadap risiko karena pada dasarnya kebijakan pemerintah telah diumumkan terlebih dahulu oleh pemerintah dan dapat dilihat trend pergerakannya oleh investor sehingga investor telah siap dengan ketidakstabilan kondisi ekonomi dan menarik sahamnya dibursa efek. Hal ini disebabkan karena investor di Indonesia tidak tertarik dengan risiko yang tinggi. sedangkan variabel mikro perusahaan yang diwakili oleh DER dan asset growth berpengaruh terhadap risiko sistematis. Debt to equity berpengaruh signifikan dan memiliki arah yang negatif terhadap risiko sistematis 


\section{JURNAL NOMINAL / VOLUME III NOMOR 2 / TAHUN 2014}

dikarenakan pendanaan dapat meningkatkan nilai perusahaan. Apabila pendanaan didanai melalui hutang peningkatkan tersebut terjadi akibat dari efek tax deductible, artinya perusahaan yang memiiki hutang akan membayar bunga pinjaman yang dapat mengurangi penghasilan kena pajak dan dapat memberi manfaat bagi pemegang saham. Selain itu, penggunaan dana ekstenal akan menambah pendapatan perusahaan yang nantinya akan digunakan untuk kegiatan investasi yang menguntungkan bagi perusahaan, sehingga semakin tinggi DER maka risiko yang ditanggung semakin kecil. Perusahaan yang memiliki asset yang banyak dapat juga meningkatkan risiko yang akan ditanggung oleh investor jika perusahaan tidak dapat menggunakan asset tersebut dan gagal melakukan ekspansi.

\section{Saran}

1. Varibel makro dan mikro berpengaruh secara signifikan terhadap risiko sistematis tetapi memiliki koefisien determinasi yang kecil sehingga perlunya mencari varibael lain yang mempengaruhi risiko.

2. Variabel makro tidak berpengaruh terhadap risiko sistematis sehingga perlunya memasukan variabel lain yang berpengaruh terhadap risiko. Sedangkan variabel mikro berpengaruh terhadap risiko sehingga sebaiknya ditambah variabel mikro yang dapat mengambarkan risiko yang akan ditanggung investor.

3. Bagi peneliti selanjutnya sebaiknya menambahkan variabel makro yang lain seperti Produk Domestik Bruto, pengumuman kebijakan pemerintah, dan harga emas karena dalam penelitian ini semua variabel makro tidak berpengaruh terhadap risiko sistematis dan peneliti selanjutnya harus memperhatikan periode penelitian yang dikhawatirkan dapat mempengaruhi hasil penelitian seperti krisis ekonomi yang melanda Indonesia.

\section{DAFTAR PUSTAKA}

Auliyah dan Hamzah,Ardi. 2006. Analisa Karakter Perusahaan, Industri dan Ekonomi Makro terhadap Return dan Beta Saham Syariah di Bursa Efek Jakarta. Simposium Nasional Akuntansi IX Padang Agustus 2006 hal 1-16.

Ang, Robert. 1997. Buku Pintar : Pasar

Modal Indonesia. Mediasoft

Indonesia Jakarta.

Dornbusch, R., Fischer, S., and Richard

Starz. 2008. Makro Ekonomi.

Terjemahan oleh : Roy Indra

Mirazudin, SE. PT Media Global

Edukasi, Jakarta. 
JURNAL NOMINAL / VOLUME III NOMOR 2 / TAHUN 2014

Fabozzi, EJ. and Francis, J.C. 1996. Capital

Market and Institution and

Instrument. Upper Saddle River New

Jersey.

Ferdinand, Augusty. 2006. Metode

Penelitian Manajemen (Edisi 1). BP

Undip. Semarang.

Frank, J, Fabozzi, franco, Modigliani dan G, Michael, Ferri. 1999. Pasar dan Lembaga Keuangan. Buku Satu. Jakarta. Salemba Empat.

Ghozali, Imam. 2011. Aplikasi Analisis

Multivariat dengan Program SPSS.

Badan Penerbit Universitas

Diponegoro, Semarang.

Hamzah,Ardi, 2005, Analisa Ekonomi Makro, Industri dan Karakteristik Perusahaan terhadap Beta Saham Syariah, Simposium Nasional Akuntansi VIII Solo September 2005 hal 367-378.

Haryanto, M.Y Dedi dan Riyatno. 2007. Pengaruh Suku Bunga Sertifikat Bank Indonesia dan Nilai Kurs terhadap Risiko Sistematik Saham Perusahaan di BEJ. Jurnal Keuangan dan Bisnis Vol 5 No 1 Maret 2007 hal 24-40.

Husnan,Suad. 2001. Dasar-dasar Teori Portofolio dan Analisis Sekuritas. Edisi Kedua. AMP YKPN. Yogyakarta.

Hooker, Mark A. 2004. Macroeconomic Factors and Emerging Market Equity
Returns: A Bayesian Model Selection Approach. Emerging Markets Review 5:379-387.

Kewal, Suramaya Suci. 2011. Pengaruh Tingkat Inflasi, Suku Bunga Sertifikat Bank Indonesia, Kurs dan Pertumbuhan Produk Domestik Bruto Terhadap Harga Saham Sektoral dan Indeks Harga Saham Gabungan di Bursa Efek Indonesia. Tesis Sarjana S2 Universitas Sriwijaya. Program Studi Magister Sains. Universitas Sriwijaya, Palembang.

Komariah, Julenah, Chudori. 2011. Return Saham, Inflasi, dan Struktur Kepemilikan Terhadap Risiko Investasi. Jurnal Keuangan dan Perbankan. Vol 15 No. 3 September2011 hal 376-391.

Krugman,Paul R. dan Maurice Obstfeld. 2005. Ekonomi Internasional Teori dan Kebijakan. Edisi kelima, jilid kedua, Penerbit Indeks. Jakarta.

Makaryanawati dan Ulum, Misbachul. 2009.

Pengaruh Tingkat Suku Bunga dan

Tingkat Likuiditas Perusahaan terhadap Risiko Investasi Saham yang Terdaftar pada Jakarta Islamic Index, Jurnal Ekonomi Bisnis Tahun 14 No 1 Maret 2009 hal 49-59.

Muljono. 2002. Analisis Faktor-Faktor Yang Mempengaruhi Risiko Sistematis Dalam Industri Barang-Barang Konsumsi Pada Bursa Efek Jakarta. 


\section{JURNAL NOMINAL / VOLUME III NOMOR 2 / TAHUN 2014}

Tesis Sarjana S-2 Universitas

Diponegoro. Magister Manajemen.

Universitas Diponegoro Semarang.

Mutia, Evi dan Muhammad, Arfan. 2010.

Analisis Pengaruh Deviden Payout

Ratio dan Capital Structure Terhadap

Beta Saham : (Studi Pada Saham

Syariah dan Saham Non Syariah

Perusahaan Non Keuangan di Bursa

Efek Indonesia). SNA XIII

Purwokerto 2010.

Nanga, Muana. 2001. Makroekonomi, Edisi

1. PT RajaGrafindo Persada. Jakarta.

Nachrowi, D.N, dan Usman, Hardius. 2006.

Pendekatan Populer dan Praktis

Ekonometrika Untuk Analisis

Ekonomi dan Keuangan. Fakultas

Ekonomi Universitas Indonesia,

Jakarta.

Nugroho,Heru. 2008. Analisis Pengaruh

Inflasi, Suku Bunga, Kurs, dan

Jumlah Uang Beredar terhadap

Indeks LQ45 (Studi Kasus Pada BEI

Periode 2002-2007). Tesis Sarjana S-

2 Magister Manajemen, Program

Studi Magister Manajemen

Universitas Diponegoro, Universitas

Diponegoro Semarang.

Ocran,Karl. 2010. Measuring The

Systematic Risk Of Companies

Listed On The Ghana Stock Exhange.

Dissertation Submitted to The

Departement of Business

Administration, Ashesi University.
Sukirno, Sadono. 2004, Makroekonomi Teori

Pengantar, edisi ketiga, PT, Grafindo

Persada, Jakarta.

Santoso, Singgih. 2000. Buku Latihan SPSS :

Statistik Non Parametrik. PT Elex

Media Komputindo, Jakarta.

Sufiyati dan Ainun Na'im. 1998. Pengaruh

Leverage Operational dan Leverage

Finansial Terhadap Risiko Sistematis

Saham : Studi Pada Perusahaan

Publik di BEJ. Jurnal Ekonomi dan

Bisnis Indonesia 1998, vol 13, No3, 57-69.

Susanto,Yudhistira. 2002. Sinyal Positif dari

Lantai Bursa. Investor No.53/IV. Jakarta.

Tandelilin, Eduardus. 1997. Determinants if Systematic Risk : The Experience of Some Indonesia Common Stock, Kelola, No. 16/IV, 101-114.

Tandelilin, Eduardus. 2001. Analisis Investasi dan Manajemen Portofolio. BPFE Yogyakarta, Yogyakarta.

Tandelilin, Eduardus. 2010. Portofolio dan Investasi : Teori dan Aplikasi. Edisi 1. Kanisius, Yogyakarta.

Tjahjawandita,Ari dan Dumairy. 2005. Pengendalian Kurs Rupiah Terhadap Dollar Amerika Serikat Melalui Suku Bunga SBI, Sosiosains, Oktober hal 639-656.

Umar,Husein. 2003, Riset Bisnis, Cetakan kedua, PT, Gramedia Pustaka Utama, Jakarta. 
Widjaja,Emilia. 2004. Analisis Pengaruh

Inflasi terhadap Tingkat Risiko

Saham (Studi Kasus Pada Saham-

Saham Kategori LQ45 Tahun 2001-

2002). Atma nan Jaya Januari-Juni

2004 hal 55-67.

Yamin,Sofyan dan Kurniawan, Heri. 2009.

SPSS Complete Teknik Analisis

Statistik Terlengkap. Salemba Empat.

Jakarta.

Bank Indonesia. Bank Central Republik Indonesia. Online. www.bi.co.id. 14 Maret 2013.

Saham Ok. Realistis Berinvestasi Saham di Bursa Efek Indonesia. Online. www.sahamok.com. 12 April 2013. 